\title{
Problematika Perlindungan Lahan Pertanian Berkelanjutan Pasca Undang-Undang Cipta Kerja
}

\author{
Sumarja $^{1}$, Eddy Rifai ${ }^{2}$, Tisnanta ${ }^{3}$, Rodhi Agung Saputra ${ }^{4 *}$ \\ I, Fakultas Hukum Universitas Lampung, Bandar Lampung, Indonesia \\ *E-mail: rodhiagungsaputra@gmail.com
}

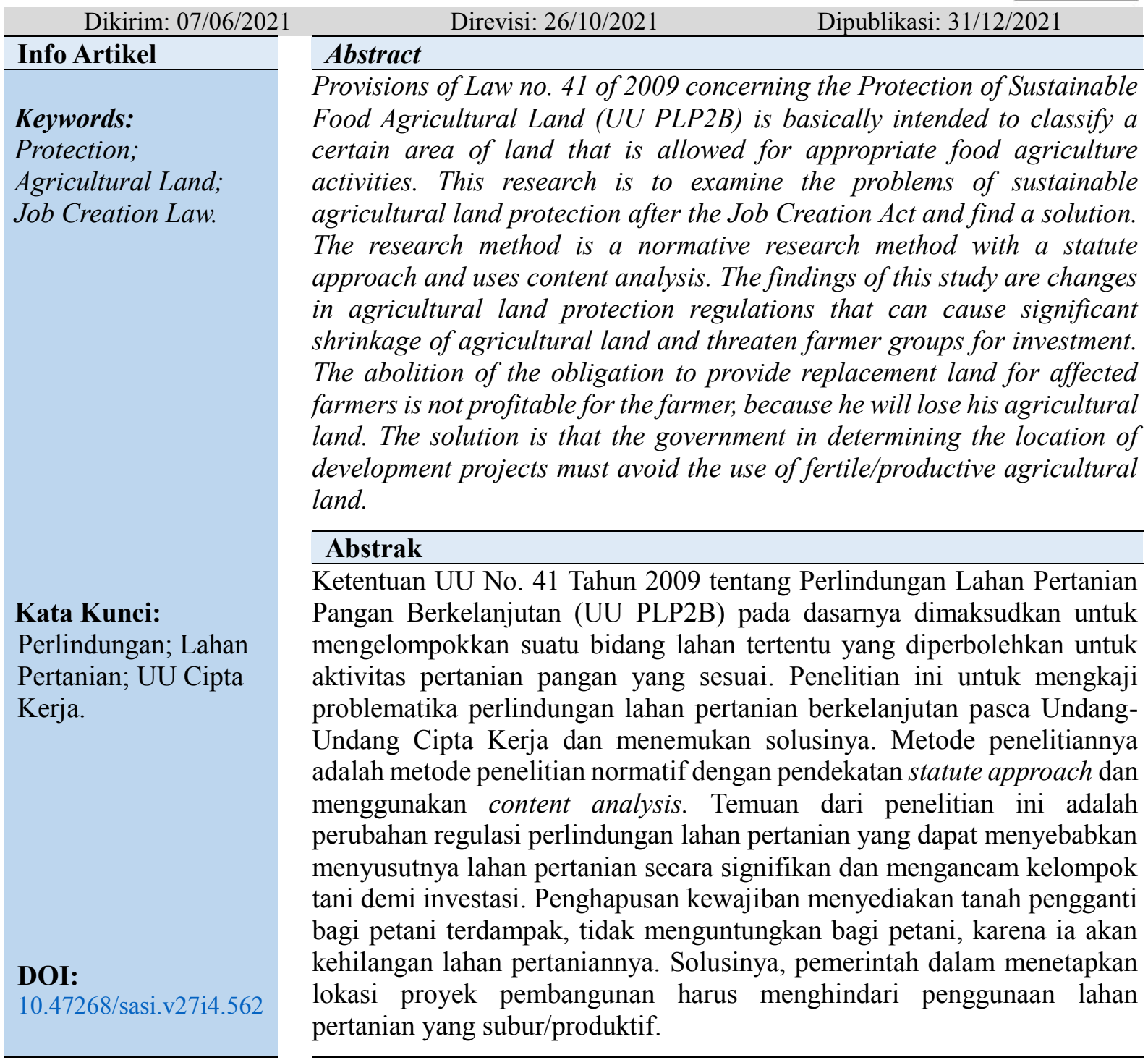

\section{A. PENDAHULUAN}

Ketentuan UU No. 41 Tahun 2009 tentang Perlindungan Lahan Pertanian Pangan Berkelanjutan (UU PLP2B) pada dasarnya dimaksudkan untuk mengelompokkan suatu bidang 
lahan tertentu yang diperbolehkan untuk aktivitas pertanian pangan yang sesuai, mengharapkan luas lahan yang diusahakan oleh petani dapat meningkat secara efektif; menjamin kesejahteraan keluarga petani; pencapaian produksi pangan sesuai kebutuhan; serta dapat mengurangi terjadinya konversi lahan yang semakin tahun semakin tak terkendali. Namun realitanya meski sudah ada regulasi terkait, sampai sekarang praktek alih fungsi lahan pertanian masih terjadi, bahkan kondisinya semakin mengkhawatirkan, hal tersebut yang melatarbelakangi mengapa dibutuhkanya perlindungan terhadap lahan pertanian. Perlindungan lahan pertanian pangan berkelanjutan merupakan sebuah sistem dan proses dalam merencanakan, menetapkan, mengembangkan, memanfaatkan, membina, mengendalikan, mengawasi lahan pertanian pangan dan kawasannya secara berkelanjutan (Pasal 1 ayat (5) UU PLP2B).

Kekhawatiran akan konversi lahan pertanian yang semakin marak terjadi membuat pemerintah gencar melalukan upaya dalam berbagai kebijakan, dikutip dari pernyataan Menteri Pertanian (Mentan) Syahrul Yasin Limpo mengatakan bahwa penurunan terhadap lahan pertanian pangan berkelanjutan menjadi tantangan tersendiri dalam mendorong ketahanan pangan nasional. Kecenderungan terhadap peningkatan lahan pertanian pangan ke nonpertanian, khususnya daerah perkotaan menjadi lahan industri dan pembangunan jalan dan lain lain, semakin tidak terkendali.

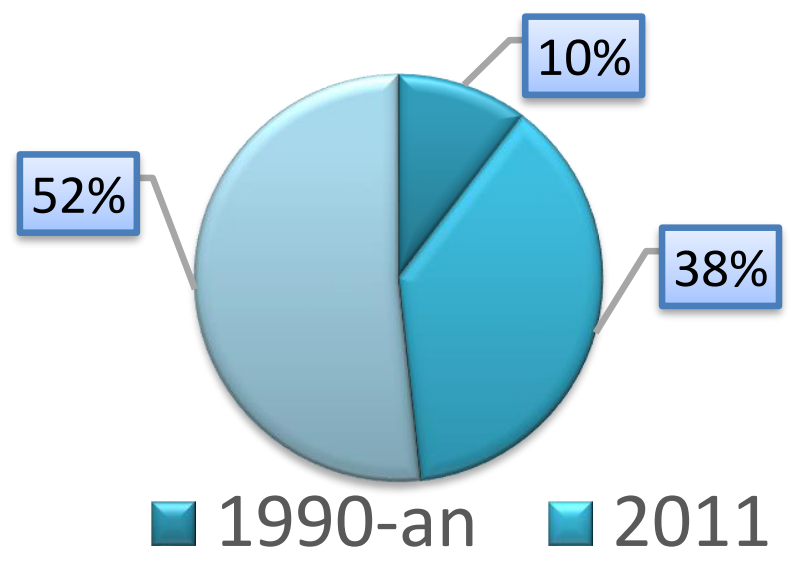

Sumber: Data Badan Pertanahan Nasional (BPN), yang diolah kembali dalam Money Kompas $2021 .^{1}$

Berdasarkan data diatas menunjukkan bahwa alih fungsi lahan yang terjadi dari tahun ke tahun terus meningkat. Pada awal tahun 1990 terjadi alih fungsi lahan seluas 30.000 ha, kembali mengalami peningkatan pada tahun 2011 seluas 110.000 ha dan di tahun terakhir pada 2019 alih fungsi lahan pertanian pangan kembali meningkat drastis menjadi seluas 150.000 ha. Hal itu, membuktikan bahwa alih fungsi lahan masih tetap terjadi walaupun sudah ada regulasi yang mengatur mengenai hal tersebut. Perlindungan hukum terhadap lahan pertanian pangan berkelanjutan sebagaimana diatur dalam UU PLP2B pada dasarnya belum cukup untuk mengakomodir permasalahan terjadinya alih fungsi lahan.Walaupun sudah ditetapkan regulasinya, namun tidak ada dampak yang terlihat secara signifikan.Alih fungsi lahan yang belum berhenti tersebut menjadi problematika tersendiri, ketika regulasi mengenai PLP2B diubah dengan Undang-Undang Nomor 11 Tahun 2020 tentang Cipta Kerja (UU Cipta Kerja). ${ }^{2}$

1 Uly, Y. A. (2021) "Mentan: Alih Fungsi Dari Lahan Pertanian Di 2019 Capai 150.000 Hektar.," MoneyKompas,https://money.kompas.com/read/2021/03/29/140755726/mentan-alih-fungsi-dari-lahanpertanian-di-2019-capai-150000-hektar.

2 Andiyani, M. A. (2021). Ancaman Distruktif Penerapan UU Cipta Kerja Terhadap Pengelolaan LahanDiIndonesia,https://www.pasundanekspres.co/opini/ancaman-destruktif-penerapan-uu-omnibus-lawcipta-kerja-terhadap-pengelolaan-lahan-di-indonesia. 
Adanya perubahan regulasi atas perlindungan lahan pertanian pangan berkelanjutan dalam UU Cipta Kerja justru akan semakin memperburuk nasib petani. Penerapannya akan semakin didegredasi dan alih fungsi lahan pertanian pada pelaksanaanya akan semakin difasilitasi dalam klaster 8 UU Cipta Kerja. Tanah pertanian masyarakat akan semakin menyusut, begitu juga dengan jumlah petani pemilik tanah dan petani penggarap akan semakin berkurang jumlahnya, akibat kehilangan alat produksi yang utama yakni tanah. Argumentasi tersebut didukung dengan adanya perubahan Pasal 44 ayat (2) UU PLP2B dalam UU Cipta Kerja, dimana frasa Proyek Strategis Nasional (PSN) ditambahkan sebagai perubahan pasal atas UU PLP2B yang ada dalam UU Cipta Kerja. Aliansi Petani Indonesia (API) menilai adanya penambahan kata PSN dalam perubahan peraturan perlindungan lahan pertanian pangan berkelanjutan dalam UU Cipta Kerja tersebut menunjukkan betapa kontradiktifnya pemerintah dengan regulasi yang sebelumnya. Sebab dengan alasan Proyek Strategi Nasional, alih fungsi lahan pertanian dapat dengan mudah dilakukan.

Proyek Strategis Nasional yang disandingkan dengan kepentingan umum menjadi tidak kompatibel dengan UU PLP2B sebelumnya, hal tersebut terlihat dari orientasi keduanya yang secara subtsansi, UU PLP2B sebelumnya jelas melindungi hak masyarakat. Pengalihfungsian yang hanya dapat dilaksanakan jika diorientasikan untuk kepentingan umum menjadi lemah posisinya ketika pemerintah juga memasukan Proyek Strategis Nasional sebagai syarat dapat dialihfungsikan-nya sebuah lahan. Selain itu kenyataan bahwa adanya UU PLP2B saja konflik mengenai penyusutan terhadap lahan pertanian sudah tak terkendali, hal tersebut tentunya akan semakin parah ketika UU Cipta Kerja di berlakukan secara substansi. Kebijakan yang diubah dengan UU Cipta Kerja tersebut akan semakin memperlebar celah dan legalisasi alih fungsi lahan. Hal diatas merupakan latar belakang atau dasar mengapa perlindungan lahan pertanian berkelanjutan perlu dilaksanakan.

Berdasarkan uraian diatas, maka yang menjadi permasalahan dalam penelitian ini adalah Bagaimanakah problematika Perlindungan Lahan Pertanian berkelanjutan Pasca UndangUndang Cipta kerja dan solusinya.

\section{B. METODE PENELITIAN}

Metode penelitian yang digunakan adalah metode penelitian normatif, ${ }^{3}$ dengan menggunakan pendekatan statute approach terkait Problematika Perlindungan Lahan Pertanian Berkelanjutan Pasca UU Cipta Kerja. ${ }^{4}$ Pendekatan statute approach yaitu mengkaji hal-hal yang menyangkut asas-asas hukum, pandangan dan doktrin-doktrin hukum, dan peraturan perundang undangan terkait lahan pertanian berkelanjutan, dan data yang akurat serta dapat dipertanggung jawabkan kebenaranya. ${ }^{5}$ Selain itu juga diadakan pemeriksaan mendalam terhadap fakta hukum tersebut untuk kemudian mengusahakan pemecahan atas permasalahan yang timbul didalam gejala yang bersangkutan. ${ }^{6}$ Data dianalisis menggunakan konten analisis.

\section{PEMBAHASAN}

\section{Perlindungan Lahan pertanian Berkelanjutan dan Permasalahanya}

Realisasi UU Cipta Kerja, UUPLP2B justru masuk dalam klaster pengadaan tanah untuk investasi, infrastruktur dan proyek strategis nasional. Menurut Penjelasan Pasal 44 ayat (2) UULP2B sebagaimana telah diubah dalam ketentuan Pasal 124 angka 1 UU Cipta Kerja, bahwa yang dimaksud kepentingan umum adalah kepentingan sebagian besar masyarakat yang meliputi kepentingan untuk pembuatan jalan umum, waduk, bendungan, irigasi, saluran air

Soetrisno, (1978), Metodologi Research, Yogyakarta: UGM, h 49.

Marzuki, P. M. (2011), Penelitian Hukum, Jakarta: Kencana Prenada Media Group, h 352.

5 Fajar, M., \& Achmad,Y. (2010), Dualisme Penelitian Hukum Normatif \& Empiris, Yogyakarta: Pustaka Pelajar, h. 34

6 Muhammad, A. K. (2004), Hukum dan penelitian Hukum, Bandung: Citra Aditya Bakti, h. 32 495|S A S Vo1. 27 No.4, Oktober - Desember 2021 
minum atau air bersih, drainase dan sanitasi, bangunan pengairan, pelabuhan, bandar udara, stasiun dan jalan kereta api, terminal, fasilitas keselamatan umum, cagaralam, serta pembangkit dan jaringan listrik. Merujuk pada penjelasan tersebut, maka produksi pangan tidak masuk dalam kepentingan umum, meskipun pangan merupakan hajat hidup umat manusia. Pangan juga tidak termasuk dalam Proyek Strategis Nasional.

Sejumlah perubahan ketentuan dinilai mengancam kelangsungan hidup petani, memperparah konflik agraria, memperbesar ketimpangan kepemilikan lahan dan praktik penggusuran demi investasi. Perubahan ini terkait persetujuan alih fungsi lahan tanah pertanian ke non-pertanian, penambahan kategori kepentingan umum dan Proyek Strategis Nasional dalam pengadaan tanah. ${ }^{7}$ Kekhawatiran tersebut dapat dipahami, mengingat ketentuan Pasal 44 ayat (3) UUPLP2B yang telah diubah dengan Pasal 124 angka 1 UU Cipta Kerja isinya sama. Sementara Pasal 44 ayat (2) UUPLP2B ditambahkan frase "Proyek Strategis Nasional" sehingga dapat artikan bahwa alih fungsi lahan pertanian pangan berkelanjutan yang digunakan untuk Proyek Strategis Nasional tidak ada kewajiban penyediaan lahan pengganti. Dalam praktik, dikhawatirkan mengabaikan syarat-syarat lain, seperti keharusan dilakukannya kajian kelayakan strategis, dan disusunnya rencana alih fungsi lahan. Perubahan tersebut dapat mempercepat alih fungsi tanah pertanian dan mengancam keberadaan kelompok petani.

\section{Tabel}

\section{Perbandingan Pasal 44 UULP2B dengan UU Cipta Kerja}

\begin{tabular}{l}
\hline \multicolumn{4}{c}{ UU PLP2B } \\
\hline Pasal 44 \\
ayat (1): Lahan yang sudah ditetapkan \\
sebagai Lahan Pertanian \\
Berkelanjutan dilindungi dan dilarang \\
dialihfungsikan. \\
ayat (2): Dalam hal untuk kepentingan \\
umum, Lahan Pertanian Pangan \\
Berkelanjutan sebagaimana dimaksud pada \\
ayat (1) dapat dialihfungsikan, dan \\
dilaksanakan sesuai dengan ketentuan \\
peraturan perundang-undangan.
\end{tabular}

ayat (3): Pengalihfungsian Lahan yang sudah ditetapkan sebagai Lahan Pertanian Pangan Berkelanjutan untuk kepentingan umum sebagaimana dimaksud pada ayat (2) hanya dapat dilakukan dengan syarat: a. dilakukan kajian kelayakan strategis; b. disusun rencana alih fungsi lahan; $c$. dibebaskan kepemilikan haknya dari pemilik; dan d. disediakan lahan pengganti terhadap Lahan Pertanian Pangan Berkelanjutan yang dialihfungsikan.

ayat (4): Dalam hal terjadi bencana sehingga pengalihan fungsi lahan untuk infrastruktur

\section{Pasal 124 angka 1}

\section{UU Cipta Kerja}

Pasal 44

ayat (1): Lahan yang sudah ditetapkan sebagai Lahan Pertanian Pangan Berkelanjutan dilindungi dan dilarang dialihfungsikan.

ayat (2): Dalam hal untuk kepentingan umum dan/atau Proyek Strategis Nasional, Lahan Pertanian Pangan Berkelanjutan sebagaimana dimaksud pada ayat (1) dapat dialihfungsikan, dan dilaksanakan sesuai dengan ketentuan peraturan perundangundangan.

ayat (3): Pengalihfungsian Lahan yang sudah ditetapkan sebagai Lahan Pertanian Pangan Berkelanjutan untuk kepentingan umum sebagaimana dimaksud pada ayat (2) hanya dapat dilakukan dengan syarat: a. dilakukan kajian kelayakan strategis; $b$. disusun rencana alih fungsi lahan; c. dibebaskan kepemilikan haknya dari pemilik; dan d. disediakan lahan pengganti terhadap Lahan Pertanian Pangan Berkelanjutan yang dialihfungsikan.

\footnotetext{
${ }^{7}$ https://nasional.kompas.com/read/2020/08/12/05200071/ancaman-terhadap-petani-dan-potensi-konflik-agrariadalam-uu-cipta-kerja 496|SASI Vo1.27 No.4, Oktober-Desember 2021
} 
tidak dapat ditunda, persyaratan sebagaimana dimaksud pada ayat (3) huruf a dan huruf $\mathrm{b}$ tidak diberlakukan.

ayat (5): Penyediaan lahan pengganti terhadap lahan pertanian pangan berkelanjutan yang dialihfungsikan untuk infrastruktur akibat bencana sebagaimana dimaksud pada ayat (4) dilakukan paling lama 24 (dua puluh empat) bulan setelah alih fungsi dilakukan.

ayat (6): Pembebasan kepemilikan hak atas tanah yang dialihfungsikan sebagaimana dimaksud pada ayat (3) huruf c dilakukan dengan pemberian ganti rugi sesuai dengan ketentuan peraturan perundang-undangan. ayat (4): Dalam hal terjadi bencana sehingga pengalihan fungsi lahan untuk infrastruktur tidak dapat ditunda, persyaratan sebagaimana dimaksud pada ayat (3) huruf a dan huruf $b$ tidak diberlakukan.

ayat (5): Penyediaan lahan pengganti terhadap lahan pertanian pangan berkelanjutan yang dialihfungsikan untuk infrastruktur akibat bencana sebagaimana dimaksud pada ayat (4) dilakukan paling lama 24 (dua puluh empat) bulan setelah alih fungsi dilakukan.

ayat (6): Pembebasan kepemilikan hak atas tanah yang dialihfungsikan sebagaimana dimaksud pada ayat (3) huruf c dilakukan dengan pemberian ganti rugi sesuai dengan ketentuan peraturan perundang-undangan.

Jumlah petani kecil (petani yang menguasai kurang dari 0,5 ha lahan per keluarga) adalah meningkat, rentang waktu 2003-20013. Pada Sensus Pertanian 2013 (SP2013) jumlah petani kecil nasional 10,9 juta keluarga (SP2003) naik menjadi 13,7 juta keluarga (SP2013). Artinya selama 10 tahun meningkat 3,8 juta keluarga. Di pulau Jawa, dari setiap empat petani, tiga adalah petani kecil. Selain itu, data Badan Pusat Statistik (BPS) menunjukkan bahwa pada tahun 2010 luas areal usaha tani padi hanya 12,870 juta ha, menyusut $0,1 \%$ dari sebelumnya 12,883 juta ha (2009). Secara keseluruhan, luas lahan pertanian, termasuk non-beras, pada tahun 2010 diperkirakan mencapai 19,814 juta ha, menurun 13\% dibandingkan tahun 2009 yang mencapai 19,853 juta ha. Kondisi seperti ini, tentunya berdampak pada kehidupan petani yang terus memburuk. Selain jumlah petani kecil semakin meningat, jumlah rumah tangga petani juga menurun. Hal ini terbukti dari hasil Sensus Pertanian (SP) 2013 yang menunjukkan penurunan dari tahun ke tahun jumlah rumah tangga petani sejak 2003, tiap tahunnya rata-rata menurun $1,75 \%$. Pada tahun 2003 terdapat 31.170 .100 rumah tangga petani menjadi 26.126 .200 rumah tangga pada tahun 2013, sehingga selama 10 tahun terakhir jumlah rumah tangga petani menurun 4.043.900. ${ }^{8}$ Sedangkan data survey Pertanian Antar Sensus tahun 2018 jumlah rumah tangga petani 27.682.117. Sehingga selama 5 tahun terakhir dari tahun 2013-2018 jumlah rumah tangga petani naik sejumlah 1.555.917. Data ini tentunya sangat positip, mungkin dikarenakan adanya program reforma agraria dengan redistribusi tanah kepada masyarakat. Hanya saja, pertumbuhan jumlah rumah tangga petani ini jangan sampai terpuruk kembali dengan adanya UU Cipta Kerja. Seperti yang terjadi pada periode 2003-2013 dimana pertumbuhan jumlah petani menurun karena masifnya pengadaan tanah untuk kepentingan umum sebelum lahirnya UU Pengadaan Tanah.

Selain itu, kewajiban menyediakan tanah pengganti bagi petani juga terhapus. Termasuk menghapus kewajiban menyediakan tanah pengganti bagi petani terdampak. Berdasarkan Laporan Kementerian Pertanian tahun 2020 terkait Perlindungan Lahan Pertanian Pangan Berkelanjutan (LP2B) menyebutkan, luas lahan baku sawah, baik beririgasi maupun non irigasi, mengalami penurunan rata-rata seluas 650 ribu hektar per tahun. Artinya, jika laju cepat konversi tanah pertanian ini tidak dihentikan, bahkan difasilitasi UU Cipta Kerja, maka tanah pertanian masyarakat akan semakin menyusut. Begitu pula jumlah petani pemilik tanah dan petani penggarap akan semakin berkurang jumlahnya akibat kehilangan alat produksinya yang

8 Sumarja, F. X., Firmansyah, A. A., \& Wijonugroho, P. (2020), Agrarian Reforms in Indonesia: A Pleasure, ICETLAWBE, 4. DOI 10.4108/eai.26-9-2020.2302580 
utama yakni tanah dan mata pencaharian petani akan semakin tergerus.Yang menjadi sorotan yaitu tambahan kategori kepentingan umum untuk pengadaan tanah. Tambahan ini dikhawatirkan akan memperparah konflik agraria. Pasal 123 angak 1 dan 2 UU Cipta Kerja yang mengubah Pasal 8 dan Pasal 10 Undang-Undang Nomor 12 tahun 2012 tentang Pengadaan Tanah Bagi Pembangunan Untuk Kepentingan Umum (UU Pengadaan Tanah). ${ }^{9}$ Pasal ini menambah empat poin kategori pengadaan tanah untuk pembangunan kepentingan umum. Keempat kategori baru itu adalah kawasan industri minyak dan gas, kawasan ekonomi khusus, kawasan industri, kawasan pariwisata, dan kawasan lain yang diprakarsai atau dikuasai oleh pemerintah pusat, pemerintah daerah, BUMN dan BUMD serta kawasan lain yang belum diatur dalam UU Cipta Kerja diatur dengan PP.

Ketentuan tersebut dapat mempermudah proses alih fungsi lahan pertanian dan berpotensi merugikan kelompok petani. Proses alih fungsi lahan yang dipermudah, akan memperparah konflik agraria, ketimpangan kepemilikan lahan, praktik perampasan dan penggusuran tanah yangmengatasnamakan pengadaan tanah untuk pembangunan dan kepentingan umum. UU Cipta Kerjaakan memperparah konflik agaria, ketimpangan, perampasan dan penggusuran tanah masyarakat. Pernyataan penambahan kategori kepentingan umum ini merupakan hambatan dan keluhan para investor terkait pengadaan dan pembebasan lahan bagi proyek pembangunan infrastruktur serta kegiatan bisnis. Lewat UU Cipta Kerja, pemerintah memperluas definisi kepentingan umum dengan menambahkan kepentingan investor pertambangan, pariwisata, industri dan Kawasan Ekonomi Khusus (KEK) ke dalam kategori kepentingan umum. Pengadaan tanah tidak dapat dilihat sebatas proses penyediaan tanah bagi pembangunan proyek infrastruktur atau industri semata. Namun, juga harus diperhitungkan dampak sistemik terkait degradasi ekonomi, sosial dan budaya pada lokasi yang menjadi obyek pengadaan tanah serta masyarakat. Harus diingat, tanpa UU Cipta Kerja, UU pengadaan tanah dalam praktiknya telah mengakibatkan konflik agraria dan penggusuran.

Dikutip dari pernyataan Prof Widiatmaka yang menyesalkan bahwa bidang pangan dan kawasan pertanian rakyat tidak menjadi bagian dari kepentingan umum ataupun proyek strategis nasional. Kendatipun UUPLP2B dihadirkan dalam rangka mengontrol laju konversi lahan sawah khususnya sawah dengan irigasi teknis sehingga dapat menopang ketahanan pangan nasional, namun lahan pertanian yang telah ditetapkan oleh Rencana Detil Tata Ruang (RDTR) sekalipun, tidak luput dari ancaman konversi ke non-pertanian jikalau di area pertanian tersebut bertepatan dengan calon lokasi yang menjadi objek kepentingan umum. Meskipun harus disediakan lahan pengganti. Tanpa lahan pengganti, maka kegiatan yang menggunakan lahan pertanian berkelajutan meskipun dengan alasan untuk kepentingan umum tidak dapat dilakukan, kecuali demi Proyek Strategis Nasional. UU Cipta Kerja yang diharapkan dapat meningkatkan investasi yang menyediakan lapangan kerja dan daya saing, menjadi tidak kompatibel dengan apa yang diamanatkan UU PLP2B sebelum adanya perubahan.

Demi investasi yang mensyaratkan diperbolehkannya alih fungsi lahan, menjadi problematika tersendiri, ketika kepentingan umum disandingkan dengan kepentingan investasi (Proyek Strategis Nasional). Tidak dijadikannya bidang pangan sebagai proyek strategis nasional maka pangan bisa dinomorduakan, dan salah satu tantangan paling berat yang tidak masuk ke dalam pertimbangan UU dan PP ini adalah ketika produksi pangan di Indonesia dilaksanakan sebagian besar oleh rakyat dengan sistem budidaya bukan oleh perusahaan. Jika hanya disiapkan lahan siap tanam lalu siapa yang akan menanam?. Meskipun ada lahan pengganti sebagai solusi dari alih fungsi lahan namun tidak jelas pihak yang akan menanam tentu hal tersebut pelaksanaanya akan sangat menyulitkan.

Selain itu adanya perubahan UU PLP2B dalam UU Cipta Kerja ini akan berdampak terhadap perusahaan-perusahaan raksasa dan investor bermodal kuat, dapat merampas secara

9 Prastyo, A. B., Saputra, R. A., Dauri, D., \& Andreas, R. (2021). Model Perlindungan dan Pengelolaan Lingkungan Hidup dalam Mewujudan Good Governance. SASI, 27(1), 84-92.

$$
\text { 498|S A I Vol. } 27 \text { No.4, Oktober - Desember } 2021
$$


mudah lahan masyarakat secara legal dengan mudah dan tetap lepas dari jeratan hukum Selama ini praktek-praktek pemindahan paksa, penggusuran dan perampasan tanah rakyat yang dilakukan oleh pemerintah dan korporasi, baik secara sendiri maupun bersama-sama sudah sering terjadi, adanya penerbitan UU Cipta Kerja ini tentunya akan semakin memperparah kondisi pertanian di Indonesia.

\section{Lahan Pertanian Berkelanjutan dalam UU PLP2B}

Perlindungan lahan pertanian pangan berkelanjutan adalah sistem dan proses dalam merencanakan dan menetapkan, mengembangkan, memanfaatkan dan membina, mengendalikan dan mengawasi lahan pertanian pangan dan kawasannya secara berkelanjutan. UU PLP2B merupakan salah satu kebijakan pemerintah dalam mengendalikan laju alih fungsi lahan pertanian di Indonesia. Pasal 3 UU PLP2B mempunyai tujuan untuk (1) melindungi kawasan dan lahan pertanian pangan secara berkelanjutan, (2) menjamin tersedianya lahan pertanian pangan secara berkelanjutan, (3) mewujudkan kemandirian, ketahanan dan kedaulatan pangan, (4) melindungi kepemilikan lahan pertanian pangan milik petani, (5) meningkatkan kemakmuran serta kesejahteraan petani dan masyarakat, (6) meningkatkan perlindungan dan pemberdayaan petani, (7) meningkatkan penyediaan lapangan kerja bagi kehidupan yang layak, (8) mempertahankan keseimbangan ekologis dan (9) mewujudkan revitalisasi pertanian. ${ }^{10}$

Perlindungan lahan pertanian pangan berkelanjutan sebagaimana diatur dalam UU PLP2B, merupakan implementasi dari Undang-Undang Dasar Negara Republik Indonesia Tahun 1945 (UUD NRI Tahun 1945) Pasal 20, Pasal 21, Pasal 27 ayat (2), Pasal 28A, Pasal 28C, dan Pasal 33. Kemudian diimplementasi lebih lanjut oleh Peraturan Pemerintah No. 1 Tahun 2011 Tentang Penetapan dan Alih Fungsi Lahan Pertanian Pangan Berkelanjutan. Mengingat masalah alih fungsi lahan pertanian pangan, terutama lahan pertanian (sawah) ke lahan non pertanian sawah dimana setiap tahun terjadi konversi lahan. Sejalan dengan itu, upaya membangun ketahanan dan kedaulatan pangan untuk mewujudkan kesejahteraan rakyat adalah hal yang sangat penting untuk direalisasikan. Dalam rangka mewujudkan ketahanan dan kedaulatan pangan perlu diselenggarakan pembangunan pertanian berkelanjutan, yang sebagian besar bidang usahanya masih bergantung pada pola pertanian berbasis lahan.

Penyusutan lahan pertanian yang digunakan sebagai objek pembangunan seringkali menyebabkan permasalahan yang kompleks. Kebutuhan lahan untuk pembangunan yang semakin banyak membuat pemerintah kerap kali mengambilalih tanah pertanian untuk dijadikan sebagai lahan pembangunan.Regulasi yang diciptakan pemerintah untuk melindungi lahan pertanian dari ancaman konversi lahan pertanian justru tidak berdaya. Konversi lahan pertanian ke non-pertanian yang semakin tahun semakin mengalami peningkatan bahkan setelah adanya UU PLP2B. Hilangnya lahan pertanian produktif ini apabila tidak dikendalikan akan mengganggu kelangsungan dan produksi yang akhirnya bisa menyebabkan terancamnya ketahanan pangan, baik itu ketahanan pangan daerah maupun nasional. Selain fungsi pasokan produksi, lahan pertanian juga mempunyai berbagai fungsi lain yaitu sebagai penyedia dan pembuka lapangan kerja, fungsi lingkungan dan fungsi wilayah tangkapan air (water catchment area). Terjadinya alih fungsi lahan pertanian ini menyebabkan hilangnya fungsi-fungsi lain tersebut. ${ }^{11}$

Penataan ruang merupakan salah satu kebijakan yang diharapkan mampu mengendalikan laju alih fungsi lahan pertanian. Amanat tersebut telah dilaksanakan dengan disahkannya

10 Abdilah, (2021), UU cipta Kerja Tetap Lindungi Petani Dan LahanPertanianhttps://mediaindonesia.com/ekonomi/356974/uu-cipta-kerja-tetap-lindungi-petani-dan-lahanpertanian.

11 Janti, G. I., Martono, E., \& Subejo, S. (2016). Perlindungan lahan pertanian pangan berkelanjutan Guna memperkokoh ketahanan pangan wilayah (Studi di Kabupaten Bantul, Daerah Istimewa Yogyakarta). Jurnal Ketahanan Nasional, 22(1), 1-22.

499|S A S V Vol. 27 No.4, Oktober - Desember 2021 
UUPLP2B. Dengan terbitnya undang-undang tersebut diharapkan dapat menekan tingginya laju alih fungsi lahan pertanian sawah. Apabila laju alih fungsi lahan pertanian dapat dikendalikan diharapkan fungsi lain seperti fungsi ekologi dapat dipertahankan dan dijaga keberadaannya. Kepemilikan dan pemanfaatan lahan harus berlandaskan pada Pasal 33 ayat (3) UUD NRI Tahun 1945 sebagai landasan yuridis konstitusional kegiatan perekonomian nasional. Berdasarkan pada Pasal 33 ayat (3) UUD NRI Tahun 1945, bumi dan air dan kekayaan alam yang terkandung di dalamnya dikuasai oleh negara dan dipergunakan untuk sebesar-besar kemakmuran rakyat.

Hak menguasai dari negara ditafsirkan sebagai tugas kewenangan di bidang hukum publik dari Negara Republik Indonesia yang sepanjang mengenai tanah meliputi: a) pengaturan dan penyelenggaraan peruntukan, penggunaan, persediaan dan pemeliharaannya; b) penentuan dan pengaturan hubungan-hubungan hukum antara orang-orang dengan tanah; dan c) penentuan dan pengaturan hubungan-hubungan hukum antara orang-orang dan perbuatan hukum yang mengenai tanah. ${ }^{12}$ Adanya fungsi sosial atas tanah, maka pemilik lahan dalam memanfaatkan lahannya tidak boleh semata-mata mementingkan kepentingan pribadinya, melainkan juga harus tunduk pada hukum dan memperhatikan kepentingan masyarakat atau kepentingan umum. Penguasaan negara untuk melindungi lahan pertanian penting untuk mencegah pengalihan fungsinya menjadi non pertanian. Alih fungsi terjadi akibat adanya desakan kebutuhan lahan untuk kepentingan lain seperti industri, perumahan, pembangunan infrastruktur, dan sebagainya. ${ }^{13}$

Akibatnya konversi atau alih fungsi lahan pertanianbanyak terjadi di hampir seluruh wilayah Indonesia, termasuk di Kabupaten Karawang, Jawa Barat dan Kabupaten Tabanan, Bali. Tanpa adanya pelindungan terhadap lahan pertanian dari pengalihan fungsinya untuk nonpertanian dikhawatirkan upaya untuk mewujudkan ketahanan pangan terancam sehingga hak rakyat atas sulit untuk dipenuhi. Alih fungsi lahan pertanian menjadi non-pertanian dikhawatirkan menurunkan produksi yang berdampak pada menurunnya jumlah atau stok di pasar. Akibatnya harga meningkat dan dikhawatirkan tidak terjangkau lagi oleh keluarga miskin. Pelindungan terhadap lahan pertanian juga penting untuk mewujudkan kesejahteraan petani/buruh tani beserta keluarganya yang menggantungkan hidupnya dari sektor pertanian. ${ }^{14}$ Desakan kebutuhan hidup menyebabkan petani mengalihkan kepemilikan lahan pertanian kepada pihak lain yang menggunakannya untuk kepentingan non pertanian. Berkurangnya lahan pertanianmenyebabkan kesejahteraan petani/buruh tani menurun karena penghasilan mereka berkurang. Bahkan mereka bisa kehilangan mata pencaharian sebagai petani/buruh tani jika lahan pertanian dialihkan untuk kepentingan lain seperti rumah atau dijual ke investor untuk kepentingan investasi.

Hukum memiliki arti yang sangat penting untuk melindungi lahan pertanian. Terkait dengan hukum, tidak ada keseragaman antar para sarjana ilmu hukum dalam memberikan pengertian mengenai hukum karena masing-masing melihat hukum dari sudut yang berbeda. ${ }^{15}$ Berpijak pada definisi mengenai hukum tersebut, maka yang dimaksud dengan pelindungan hukum lahan pertanian dalam tulisan ini adalah keseluruhan ketentuan hukum untuk melindungi lahan pertanian dari pengalihan fungsi menjadi non-pertanianyang harus ditaati dan terhadap pelanggarnya dikenakan sanksi. Pelindungan hukum terhadap lahan pertanian dapat

12 Hasni, (2013), “Mempersoalkan Hukum dan Keadilan Dalam Rangka Penerapan Kebijakan Bidang Pertanahan, Penataan Ruang, dan Pengelolaan Lingkungan Hidup”, dalam Hukum dan Keadilan (Aspek Nasional \& Internasional), editor: Amad Sudiro dan Debi Bram, Jakarta: RajaGrafindo Persada, h 328.

13 Kusumawati, Mustika Prabaningrum. (2021), Penyusutan Lahan Pertanian dan UU Ciptaker https//Penyusutan Lahan Pertanian dan UU Ciptaker-KRJOGJA.

${ }^{14}$ Chofyan, I., Rustan, U., \& Hariyanto, A. (2016). Upaya Mempertahankan Kabupaten Karawang Sebagai Lumbung Padi Nasional. ETHOS: Jurnal Penelitian dan Pengabdian kepada Masyarakat, 4(1), 149-160.

15 Rejekiningsih, T. (2016). Asas Fungsi Sosial Hak Atas Tanah Pada Negara Hukum (Suatu Tinjauan Dari Teori, Yuridis Dan Penerapannya Di Indonesia). Yustisia Jurnal Hukum, 5(2), 298-325. 
dilakukan baik secara preventif maupun represif. Upaya preventif yang penting adalah melindungi dan memberdayakan petani, kelompok petani, koperasi petani, serta asosiasi petani. Pelindungan dan pemberdayaan tersebut diamanatkan dalam Pasal Perlindungan dan pemberdayaan penting untuk mewujudkan kesejahteraan petani/buruh tani. Sebagaimana telah dipaparkan, kesejahteraan petani/buruh tani dapat mencegah terjadinya pengalihan fungsi lahan pertanian pangan. Selain preventif, pelindungan hukum terhadap lahan pertanian juga dilakukan secara represif. ${ }^{16}$ Lahan Pertanian Pangan Berkelanjutan (LP2B) adalah bidang lahan pertanian yang ditetapkan untuk dilindungi dan dikembangkan secara konsisten guna menghasilkan bagi kemandirian, ketahanan, dan kedaulatan pangan nasional. ${ }^{17}$

\section{Lahan Pertanian Berkelanjutan Dalam Undang-Undang Cipta Kerja}

Ketika membahas kebijakan perlindungan lahan pertanian pangan berkelanjutan sudah barang tentu harus berangkat dari kerangka berpikir yang ditujukan untuk kemakmuran rakyat dan harus melihat penjabarannya secara komprehensif dalam dimensi hukum penataan ruang. Perubahan undang-undang pertanian pangan berkelanjutan dalam UU Cipta Kerja merupakan sebuah kondisi yang dipaksakan, substansi yang ada didalam UU Cipta Kerja khususnya klaster 8 tersebut.Perubahan satu pasal ini memberikan dampak yang sangat luar biasa terhadap jumlah lahan pertanian yang menyokong kebutuhan pangan masyarakat serta memberikan dampak bagi nasib petani di Indonesia. Sudah 60 tahun UUPA berlaku hingga saat ini namun keberadaannya masih memiliki marwah yang luar biasa.

Perjalanan panjang dalam proses pembentukannya kurang lebih selama 12 tahun nyatanya memang tidak main-main dan tidak memikirkan kepentingan pribadi atau politiknya semata. Para pembentuk UUPA benar-benar memikirkan nasib Bangsa Indonesia tidak hanya sebatas satu tahun, lima tahun atau sepuluh tahun, tetapi hingga puluhan tahun ke depan. Namun, perubahan Pasal 44 UU PLP2B dalam UU Cipta Kerja justru menghianati tujuan utama dari UUPA. Berbagai kemudahan diberikan dalam rangka alih fungsi lahan untuk kepentingan umum terhadap lahan yang sudah ditetapkan sebagai Lahan Pertanian Pangan Berkelanjutan, demi Proyek Strategis Nasional, yaitu dengan menghapus tiga (3) syarat utama. Syarat itu adalah: 1) adanya kajian kelayakan strategis, 2) penyusunan rencana alih fungsi lahan, dan 3) penyediaan lahan pengganti terhadap Lahan Pertanian Berkelanjutan yang dialihfungsikan.

Penghapusan ini jelas akan berdampak pada penyusutan lahan pertanian. Ketiga persyaratan yang sudah ada sebelumnya saja masih belum mampu menekan laju penyusutan lahan pertanian apalagi ketika persyaratan ini dihapuskan dan hanya digantikan dengan kalimat dilaksanakan sesuai dengan peraturan perundang-undangan yang berlaku. Seharusnya ketiga persyaratan yang sudah ada sebelumnya lebih dipertajam dan didukung dengan persyaratan tambahan agar menghindari penyusutan lahan pertanian dengan mengatasnamakan kepentingan umum. Ketika persyaratan berkaitan dengan alih fungsi Lahan Pertanian Pangan Berkelanjutan yang sudah diakomodir secara terperinci kemudian dihapuskan demi Proyek Strategis Nasional, bagaimana dengan nasib jumlah lahan pertanian yang kian hari kian menyusut. Bagaimana pula dengan nasib para petani atau buruh tani. Indonesia kemudian 'menyerahkan' begitu saja lahan pertanian yang memang sudah ditetapkan sebagai lahan pertanian pangan berkelanjutan dialihfungsikan demi Proyek Strategis Nasional setelah adanya perubahan Pasal 44 ayat (2) UU PLP2B oleh UU Cipta Kerja.

Indonesia menyebut diri dan dielu-elukan, dibanggakan sebagai negara agraris, namun pada kenyataanya sebutan Indonesia sebagai negara agraris hanya tinggal sebuah cerita. Keterbatasan jumlah lahan pertanian yang kian hari kian berkurang, didukung jumlah petani yang lebih tepat disebut buruh tani karena mayoritas mereka mengerjakan lahan pertanian milik

16 Permadi, I. (2016). Perlindungan Hukum Terhadap Pembeli Tanah Bersertifikat Ganda dengan Cara Itikad Baik demi Kepastian Hukum. Yustisia Jurnal Hukum, 5(2), 448-467.

17 Pasal 1 angka 3 UU No. 41 Tahun 2009

$$
\text { 501|SASI Vo1. } 27 \text { No.4, Oktober - Desember } 2021
$$


orang lain. Kini nasibnya petani kian tidak menentu jika pelaksanaan UU Cipta Kerja tidak bijak.

\section{Solusi Perlindungan Lahan Pertanian Berkelanjutan}

Solusi dari adanya kelemahan implementasi UU PLP2PB dan kekhawatiran pelaksanaan UU Cipta Kerja terhadap keberadaan lahan pertanian berkelanjutan sebenarnya sejak tahun 1974 pemerintah telah memiliki regulasi untuk menekan atau menghindari terjadinya alih fungsi lahan pertanian. Pencegahan terhadap alih fungsi lahan pertanian termuat dalam Peraturan Menteri Dalam Negeri No. 5 tahun 1974 tentang Ketentuan-Ketentuan Mengenai Penyediaan Dan Pemberian Tanah Untuk Keperluan Perusahaan jo. Peraturan Menteri Dalam Negeri No. 3 tahun 1987 tentang Penyediaan Dan Pemberian Hak Atas Tanah Untuk Keperluan Perusahaan Pembangunan Perumahan. Kedua regulasi tersebut dengan tegas mengatur bahwa dalam menetapkan lokasi perusahaan: a. sejauh mungkin harus dihindarkan pengurangan areal tanah pertanian yang subur; b. sedapat mungkin dimanfaatkan tanah yang semula tidak atau kurang produktif; c. dihindarkan pemindahan penduduk dari tempat kediamannya; d. diperhatikan persyaratan untuk mencegah terjadinya pengotoran/pencemaran bagi daerah lingkungan yang bersangkutan; e. mentaati rencana tata ruang wilayah/rencara tata ruang kota. ${ }^{18}$ Memperhatikan regulasi tersebut, jika pemerintah mau konsisten baik pembangunan untuk kepentingan umum yang diprakarsai pemerintah ataupun bekerjasama dengan swasta demi investasi termasuk untuk memenuhi kubutuhan lahan dalam rangka proyek strategis nasional, lahan pertanian berkelanjutan tetap dapat dipertahankan dan terlindungi.

\section{P E N U T U P}

Berdasarkan hasil penelitian terkait problematika perlindungan lahan pertanian berkelanjutan pasca UU Cipta Kerja, maka dapat diambil kesimpulan bahwa, ketentuan dalam UU Cipta Kerja terkait pengadaan lahan pertanian akan berdampak pada penyusutan lahan pertanian dan akan lebih menguntungkan investor berkedok Proyek Strategis Nasional. Sejumlah perubahan ketentuan dinilai mengancam kelangsungan hidup petani, ketentuan ini terdapat dalam Pasal 124 angka 1 UU Cipta Kerja, yang menghapus Pasal 44 ayat (3) UU PLP2B dan tambahan kategori kepentingan umum untuk pengadaan tanah. Tambahan ini dikhawatirkan akan memperparah konflik agraria. Pasal 123 angka 1 dan 2 UU Cipta Kerja yang mengubah Pasal 8 dan Pasal 10 UU Pengadaan Tanah. Campur tangan investasi yang dijadikan sebagai salah satu syarat alih fungsi dapat menjadi problematika tersendiri, ketika kepentingan umum disandingkan dengan kepentingan investasi (Proyek Strategis Nasional). Dengan tidak dijadikannya pangan sebagai proyek strategis nasional maka pangan bisa dinomorduakan, dan salah satu tantangan paling berat yang tidak masuk ke dalam pertimbangan UU dan PP ini adalah ketika produksi pangan di Indonesia dilaksanakan sebagian besar oleh rakyat dengan sistem budidaya bukan oleh perusahaan. Oleh karena itu ketentuan dalam UU Cipta Kerja ini sangat menguntungkan perusahaan-perusahaan raksasa dan investor bermodal kuat untuk dapat merampas lahan masyarakat kecil secara legal. Untuk mengatasi terjadinya alih fungsi lahan agar lahan pertanian berkelanjutan terlindungi, pemerintah harus konsisten dalam menentukan/ menetapkan lokasi proyek pembangunan dengan menghindari penggunaan lahan pertanian yang subur/produktif.

\section{DAFTAR PUSTAKA}

\section{Jurnal}

[1] Amriyanto, A. (2017). Menakar Nilai Agama dan Moral dalam Hukum Pidana Indonesia. Khairun Law Journal, 1(1), 62-72.

[2] Chofyan, I., Rustan, U., \& Hariyanto, A. (2016). Upaya Mempertahankan Kabupaten

18 Sumarja, FX. (2008), Hukum Tata Guna Tanah di Indonesia, (Bandar lampung :Unila Press, h 101-102. 502|SASI Vo1. 27 No.4, Oktober - Desember 2021 
Karawang Sebagai Lumbung Padi Nasional. ETHOS: Jurnal Penelitian dan Pengabdian kepada Masyarakat, 4(1), 149-160.

[3] Rejekiningsih, T. (2016). Asas Fungsi Sosial Hak Atas Tanah Pada Negara Hukum (Suatu Tinjauan Dari Teori, Yuridis Dan Penerapannya Di Indonesia). Yustisia Jurnal Hukum, 5(2), 298-325.

[4] Permadi, I. (2016). Perlindungan Hukum Terhadap Pembeli Tanah Bersertifikat Ganda dengan Cara Itikad Baik demi Kepastian Hukum. Yustisia Jurnal Hukum, 5(2), 448-467.

[5] Prastyo, A. B., Saputra, R. A., Dauri, D., \& Andreas, R. (2021). Model Perlindungan dan Pengelolaan Lingkungan Hidup dalam Mewujudan Good Governance. SASI, 27(1), 84-92.

[6] Sumarja, F. X., Firmansyah, A. A., \& Wijonugroho, P. (2020), Agrarian Reforms in Indonesia: A Pleasure, ICETLAWBE, 4. DOI 10.4108/eai.26-9-2020.2302580.

\section{Buku}

[7] Fajar, M., \& Achmad,Y. (2010), Dualisme Penelitian Hukum Normatif \& Empiris, Yogyakarta: Pustaka Pelajar.

[8] Hasni, (2013), "Mempersoalkan Hukum dan Keadilan Dalam Rangka Penerapan Kebijakan Bidang Pertanahan, Penataan Ruang, dan Pengelolaan Lingkungan Hidup”, dalam Hukum dan Keadilan (Aspek Nasional \& Internasional), editor: Amad Sudiro dan Debi Bram, Jakarta: RajaGrafindo Persada.

[9] Janti, G. I., Martono, E., \& Subejo, S. (2016). Perlindungan lahan pertanian pangan berkelanjutan Guna memperkokoh ketahanan pangan wilayah (Studi di Kabupaten Bantul, Daerah Istimewa Yogyakarta). Jurnal Ketahanan Nasional, 22(1), 1-22.

[10] Marzuki, P. M. (2011), Penelitian Hukum, Jakarta: Kencana Prenada Media Group.

[11] Muhammad, A. K. (2004), Hukum dan penelitian Hukum, Bandung: Citra Aditya Bakti.

[12] Sumarja, FX. (2008), Hukum Tata Guna Tanah di Indonesia, (Bandar lampung :Unila Press, h 101-102.

[13] Soetrisno, (1978), Metodologi Research, Yogyakarta: UGM.

\section{Online/World Wide Web, dll}

[14]Abdilah, (2021), UU cipta Kerja Tetap Lindungi Petani Dan LahanPertanianhttps://mediaindonesia.com/ekonomi/356974/uu-cipta-kerja-tetaplindungi-petani-dan-lahan-pertanian.

[15] Andiyani, M. A. (2021). Ancaman Distruktif Penerapan UU Cipta Kerja Terhadap Pengelolaan LahanDiIndonesia,https://www.pasundanekspres.co/opini/ancamandestruktif-penerapan-uu-omnibus-law-cipta-kerja-terhadap-pengelolaan-lahan-diindonesia.

[16] https://nasional.kompas.com/read/2020/08/12/05200071/ancaman-terhadap-petani-danpotensi-konflik-agraria-dalam-uu-cipta-kerja.

[17] Kusumawati, Mustika Prabaningrum. (2021), Penyusutan Lahan Pertanian dan UU Ciptaker https//Penyusutan Lahan Pertanian dan UU Ciptaker-KRJOGJA.

[18]Uly, Y. A. (2021) “Mentan: Alih Fungsi Dari Lahan Pertanian Di 2019 Capai 150.000 Hektar.," MoneyKompas,https://money.kompas.com/read/2021/03/29/140755726/mentanalih-fungsi-dari-lahan-pertanian-di-2019-capai-150000-hektar. 